\title{
Growth of the dusky grouper Epinephelus marginatus (Linnnaeus, 1758) (Teleostei, Serranidae), in the Natural Marine Reserve of Lavezzi Islands, Corsica, France*
}

\author{
J.-L. BOUCHEREAU ${ }^{1}$, P. BODY ${ }^{1}$ and C. CHAUVET ${ }^{2}$ \\ ${ }^{1}$ Laboratoire d'Hydrobiologie Marine et Continentale, UMR-CNRS 5556, Université Montpellier II, \\ Place Eugène Bataillon, cc093, 34095 Montpellier cedex 05. \\ ${ }^{2}$ Laboratoire d'Etude des Ressources Vivantes et de l'Environnement Marin, Université Française du Pacifique, \\ B.P.4477, Nouméa, Nouvelle Calédonie.
}

\begin{abstract}
SUMMARY: The growth of Epinephelus marginatus living in the Natural Marine Reserve of the Lavezzi Islands was studied using the von Bertalanffy model. The growth parameters of this model were: $\mathrm{L}_{\infty}=135.9 \mathrm{~cm}, \mathrm{~K}=0.08$, to $=-0.80$ years. The relationship between length and weight was $\mathrm{W}=12.510^{-2} \mathrm{TL}^{2.60}$. Grouper lengths were similar in the Lavezzi Islands and in North Tunisia. The relative abundance of trophic resources in the Lavezzi Islands, due to a positive "reserve" effect and enhanced by a small population density of groupers, has great consequences on growth, compensating the effect of lower water temperature. A plausible explanation for the similarity between these two populations is that they belong to a single metapopulation.
\end{abstract}

Key words: Serranidae, Epinephelus marginatus, growth, Mediterranean Sea, marine reserve, Corsica.

\section{INTRODUCTION}

The distribution of the dusky grouper Epinephelus marginatus (ex E. guaza) (Linnnaeus, 1758) extends from the English Channel (Wheeler et al., 1975) to southern Africa (Smith in Tortonese, 1954) as well as the Mediterranean (Tortonese, 1954; 1967). The highest abundances are found in the African coast, from Tunisia to Senegal (Franqueville and Fréon 1976, Bruslé, 1985; Chauvet, 1991). Tortonese (1954) and Smith (1971) reported this species in the east coast of South America, but without certainty as based on the determination of only six individuals.

\footnotetext{
*Received April 23, 1998. Accepted January 18, 1999.
}

Epinephelus marginatus is often described as a territorial and sedentary fish, but Chauvet and Francour (1990), and Chauvet et al. (1991), show that sedentary phases alternate occasionlly with wandering phases. Smith (1959), Atz (1964) and Bruslé and Bruslé (1975) described the presence of hermaphrodite protogynous sexuality in this species. These last authors place the sexual maturity at $5 \mathrm{~kg}$ and Chauvet (1988) at the age of 5 years. Sexual inversion occurs between 8 and 16 years in Tunisia (Chauvet, 1988). E. marginatus is currently being reclassified as a protected species in the Mediterranean and is listed in many red books as a threatened species (MNHN, 1987; Boudouresque et al., 1991). In France, this endangered species is protected by the 
national decree of April 1993 and by Prefectorial orders concerning the control of spear fishing in French waters.

The growth of E. marginatus was studied in Tunisia by Rafail et al. (1969), Chauvet (1981, 1988) and Bouain (1984) and in Algeria by Kara and Djerbal (1995). The study of Rafail focused on 251 individuals, one to seven years old, caught from the Levantine Sea. Chauvet studied 107 individuals in 1981, completed by 163 individuals in 1988, aged from one to 36 years all captured by spear fishing in the North and North-East coasts of Tunisia. The study of Bouain focused on 109 individuals aged from one to 19 years sampled when landed in fishing harbours from the oriental coast of Tunisia. The study of Kara and Djerbal focused on 33 individuals captured in the Algerian east coast, aged from at least one to seven years as it was not possible to read scales beyond this age.

The present study of the growth of E. marginatus concerns specimens sampled in the Natural Marine Reserve of the Lavezzi Islands located to the south of Corsica in the Bouches de Bonifacio (Fig. 1). The results are compared to those provided in the five papers cited.

\section{MATERIAL AND METHODS}

The biological material studied is made up of scales collected during surveys of fish landed by fishermen between August 1990 and July 1993. Although age reading on otolithes was considered, it was not possible to remove the otolithes because the fishermen wished to keep the fish intact for sale. Scales were taken from between the lateral line and the dorsal fin. The sample includes 24 individuals from artisanal fishing undertaken in the Natural Marine Reserve in the Lavezzi Islands (Fig. 1).

Total length (TL in $\mathrm{cm}$ ) and weight (W in $\mathrm{g}$ ) of individuals were measured on board the fishing boat when scales were extracted. Two to ten scales were sampled on each grouper. Size and weight of the different individuals ranged between 20 and $120 \mathrm{~cm}$, and between 0.7 and 24 $\mathrm{kg}$ respectively.

As it was not possible to validate the growth by independent means, for example the injection of tetracycline, the rhythm of the growth annuli observed on scales was determined by analogy to the previous works of Bouain (1984) and Chauvet

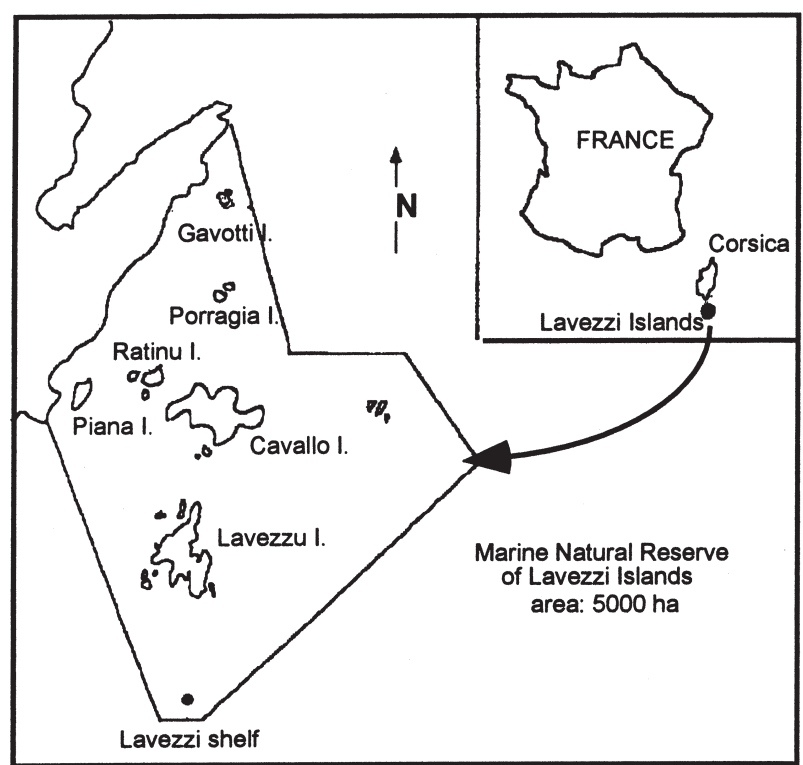

FIG. 1. - Geographical situation of the Natural Marine Reserve of the Lavezzi Islands.

(1988) and fixed to one year. The size of each fish was back calculated for all ages (Lee, 1920). Age determination and the measurement of distances from the center of the scale to the annuli (Fig. 2) were carried out under a microscope coupled to an image analysis system (Lam Hoai, 1992; Grill, 1989).

The mean length by age class was used to calculate the growth curve and determine the growth parameters of the von Bertalanffy model (1934). A maximum age was calculated with the relative increase $[(\mathrm{TL}+1-\mathrm{TL}) / \mathrm{TL}]$. According to Chauvet (1988), after the age of 12 years, the relative increase of the body size decreases in a linear manner. He calculated the relationship between the relative linear increase and time $(\mathrm{dTL} / \mathrm{TL}=\mathrm{f}(\mathrm{t}))$, considering size values at ages of 12 years and more. This author obtained sizes of fish up to a maximum age at which the relative increase is null. The von Bertalanffy's parameters were calculated with a computer program written in BASIC by Lam Hoai (1989) using the Tomlinson and Abramson's method (1961) to study populations and ecosystems. According to Chauvet (1988), this method that minimizes the quadratic gaps, gives results influenced by the largest individuals of the sample. He prefered to use at that time Walford's method (1946) which minimizes the reduced quadratic gaps that attribute the same weight to all individuals of the sample. 

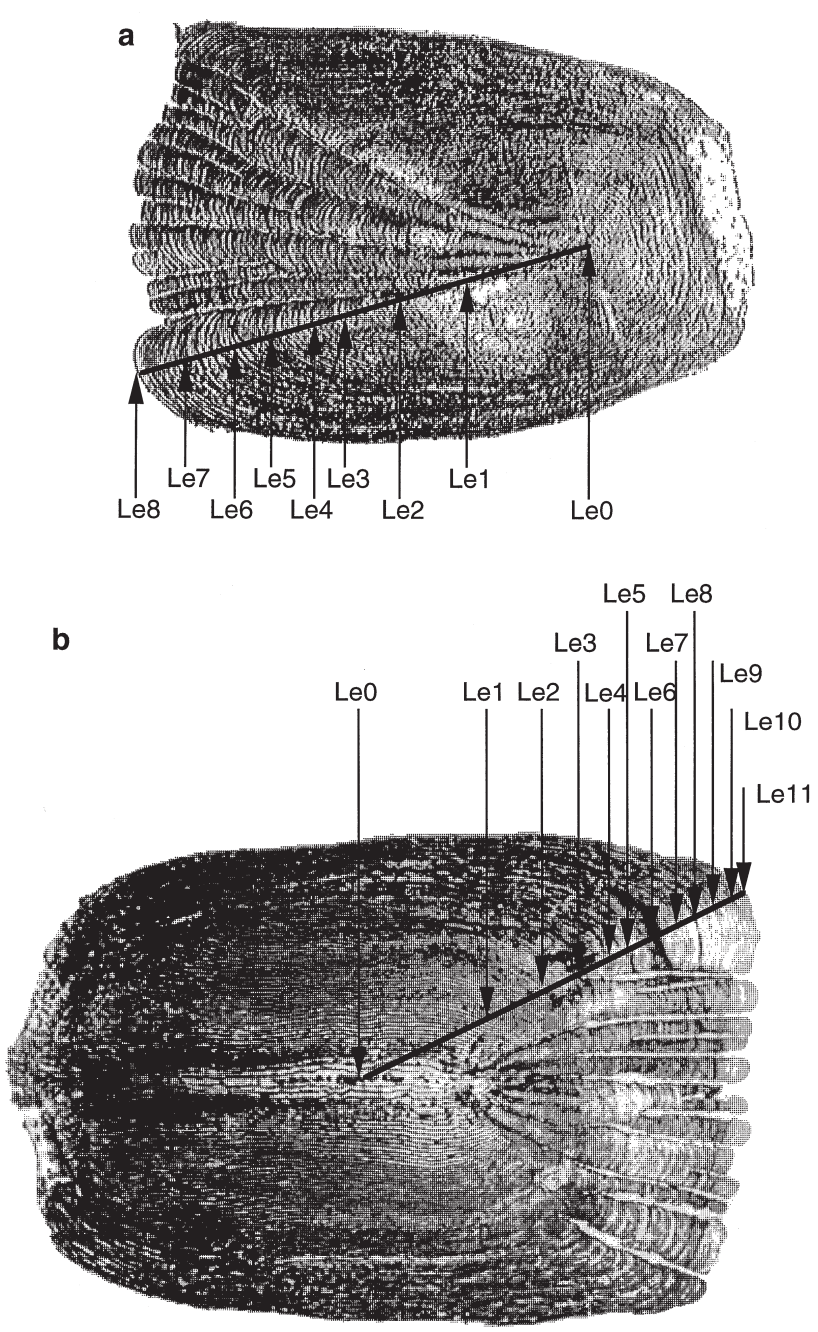

FIG. 2. - Measurements undertaken on two scales of $7 \mathrm{~mm}$ (a) and $13 \mathrm{~mm}$ (b) of two groupers $E$. marginatus respectively aged 8 years $(\mathrm{TL}=60 \mathrm{~cm})$ and 11 years $(\mathrm{TL}=75 \mathrm{~cm})$; Le0: center of the scale; Len: radius of the scale from 1 to $n$ years.
The von Bertalanffy' relation is :

$$
\mathrm{TL}=\mathrm{L}_{\infty}\left(1-\mathrm{e}^{-\mathrm{K}\left(\mathrm{t}-\mathrm{t}_{0}\right)}\right)
$$

where: TL: total length; $\mathrm{L}_{\infty}$ : asymptotic length; $\mathrm{K}$ : annual growth rate; $\mathrm{t}$ : age in years; $\mathrm{t}_{0}$ : age at which $\mathrm{TL}=0$.

The length - weight relationship was determined from size and weight measurements on 24 individuals using the equation:

$$
\mathrm{W}=\mathrm{aLT}^{\mathrm{b}}
$$

where: W: weight in g; TL: total length in $\mathrm{cm}$; a: coefficient related to the density and proportion of fish; b: allometry ratio.

Parameters a and $b$ were obtained by a linear adjustment to the lesser rectangles realized on the logarithmic transformation of the equation.

\section{RESULTS}

We have no data on the age of two fishes because scales were unreadable.

The best relationship grouper size - scale size was the form: $\mathrm{y}=a x b$ and $\log \mathrm{y}=\operatorname{blog} \mathrm{x}+\log \mathrm{a}$ when linearised.

After calculation: $\log \mathrm{TL}=0.695 \log \mathrm{Le}+2.418$, and the equation is: $\mathrm{TL}=261.82 . \mathrm{Le}^{0.695}$

with: TL: length of the fish $(\mathrm{mm})$ and Le: radius of the scale $(\mathrm{mm})$.

The correlation coefficient was $r=0.648$; determination coefficient: $\mathrm{r}^{2}=0.391$.

TABLE 1. - Mean values of the size $\left(\mathrm{TL}_{\mathrm{back}}\right.$ in $\mathrm{cm}$ ) obtained by back-calculation at different ages (in years) for E. marginatus; n: number of fish specimens; $\mathrm{n}_{\text {cum }}$ : cumulated number; $\mathrm{TL}_{\min }$ : minimum length; $\mathrm{TL}_{\max }$ : maximum length; $\sigma$ : standard deviation; $\mathrm{dL}$ : absolute increase; $\mathrm{dL} / \mathrm{L}$ :

\begin{tabular}{|c|c|c|c|c|c|c|c|c|}
\hline age & $\mathrm{n}$ & $\mathrm{n}_{\mathrm{cum}}$ & $\mathrm{TL}_{\text {back }}$ & $\mathrm{TL}_{\min }$ & $\mathrm{TL}_{\max }$ & $\sigma$ & $\mathrm{dL}$ & $\mathrm{dL} / \mathrm{L}$ \\
\hline 1 & 0 & 22 & 16.52 & 11.34 & 23.99 & 3.14 & - & \\
\hline 2 & 1 & 22 & 27.92 & 20.15 & 41.55 & 5.32 & 11.40 & 0.690 \\
\hline 3 & 0 & 21 & 36.74 & 25.44 & 50.40 & 6.77 & 8.82 & 0.316 \\
\hline 4 & 1 & 21 & 43.50 & 28.76 & 59.68 & 7.82 & 6.76 & 0.184 \\
\hline 5 & 0 & 20 & 49.88 & 32.06 & 66.11 & 8.14 & 6.38 & 0.147 \\
\hline 6 & 2 & 20 & 55.93 & 37.02 & 70.80 & 8.21 & 6.05 & 0.121 \\
\hline 7 & 1 & 18 & 62.55 & 42.32 & 78.42 & 8.50 & 6.62 & 0.118 \\
\hline 8 & 1 & 17 & 67.95 & 47.61 & 85.42 & 9.07 & 5.40 & 0.086 \\
\hline 9 & 1 & 16 & 73.20 & 55.23 & 91.29 & 8.88 & 5.25 & 0.077 \\
\hline 10 & 3 & 15 & 77.65 & 58.85 & 97.73 & 9.32 & 4.45 & 0.061 \\
\hline 11 & 0 & 12 & 82.77 & 62.47 & 106.51 & 11.16 & 5.12 & 0.066 \\
\hline 12 & 4 & 12 & 85.77 & 65.12 & 109.44 & 11.92 & 3.00 & 0.036 \\
\hline 13 & 1 & 8 & 90.29 & 70.09 & 114.13 & 13.64 & 4.52 & 0.053 \\
\hline 14 & 7 & 7 & 94.73 & 74.06 & 120.00 & 15.54 & 4.44 & 0.049 \\
\hline
\end{tabular}
relative increase (scales of two specimens were not readable). 
$\log$ a is supposed to represent the length of the fish when the scales appear, and helps normally to correct results of the back-calculation (Lee, 1920). Given the value found $(2.418 \mathrm{~mm})$ it is impossible to observe scales on a fish of such size, therefore the back-calculation has not been corrected. This can be explained by the absence of very small specimens.

TABLE 2. - Mean lengths TL (in $\mathrm{cm}$ ) calculated from the adjustment of the linear increase according to the time, for age classes of $E$. marginatus from 15 to 26 years; absolute increase: $\mathrm{dL}=\mathrm{TL}+1-\mathrm{TL}$; relative increase: $\mathrm{dL} / \mathrm{TL}$.

\begin{tabular}{lrrr}
\hline age & $\mathrm{TL}$ & $\mathrm{dL}$ & $\mathrm{dL} / \mathrm{TL}$ \\
& & & \\
\hline 15 & 98.70 & 3.97 & 0.0419 \\
16 & 102.47 & 3.77 & 0.0382 \\
17 & 106.01 & 3.54 & 0.0345 \\
18 & 109.28 & 3.27 & 0.0308 \\
19 & 112.24 & 2.96 & 0.0271 \\
20 & 114.87 & 2.63 & 0.0234 \\
21 & 117.13 & 2.26 & 0.0197 \\
22 & 119.00 & 1.87 & 0.0160 \\
23 & 120.46 & 1.46 & 0.0123 \\
24 & 121.50 & 1.04 & 0.0086 \\
25 & 122.10 & 0.60 & 0.0049 \\
26 & 122.25 & 0.15 & 0.0012 \\
\hline
\end{tabular}

\section{Linear growth and age estimation}

Given the low sampling size, means of lengths have been obtained up to the age of 14 years (Table 1). From 14 to 26 years, mean lengths were calculated by using the extrapolation of the regression between relative increases of lengths and age (Table 2):

$$
\mathrm{dL} / \mathrm{L}=-3.7 .10^{-3} \mathrm{t}+0.0974
$$

Correlation coefficient: $r=-0.5044$.

The linear growth parameters of the von Bertalanffy model are presented in Table 3. Growth parameters of Epinephelus marginatus obtained in Lavezzi are not significantly different from those of Tunisia (Chauvet (1988) but differ from those obtained for this species in Egypt (Rafail et al., 1969), south Tunisia (Bouain, 1984) and Algeria (Kara and Derbal, 1995) (Table 4). Growth curves (Fig. 3) show that the groupers from the Lavezzi Islands, at the same age as those from Tunisia, are of a slighty larger size.

TABLE 3. - Growth Parameters of the von Bertalanffy model for E. marginatus from the Lavezzi Islands; $\sigma$ : standard deviation.

\begin{tabular}{lcccccc}
\hline age class & $\mathrm{L}_{\infty}(\mathrm{cm})$ & $\sigma$ & $\mathrm{K}$ & $\sigma$ & $\mathrm{t}_{0}$ & $\sigma$ \\
\hline 1-14 years & 135.91 & 19.23 & 0.0791 & 0.0207 & -0.8032 & 0.4311 \\
$1-26$ years & 147.89 & 10.99 & 0.0695 & 0.0126 & -0.8936 & 0.6058 \\
\hline
\end{tabular}

TABLE 4. - Comparison of sizes of E. marginatus and growth parameters of the von Bertalanffy model (L, K, $t$ at age 0$)$ from 5 different studies; Lavezzi: present work; North Tunisia: Chauvet (1988); Egypt: Rafail et al. (1969); South Tunisia: Bouain (1984); East Algeria: Kara and Derbal (1995); $\sigma$ : standard deviation; t: Student's parameter for the comparison of values from the Lavezzi Islands and North Tunisia; ns: no significant difference; *: significant difference $(\mathrm{t}<0.05)$.

\begin{tabular}{|c|c|c|c|c|c|c|c|c|}
\hline age & $\begin{array}{c}\text { Lavezzi } \\
\text { TL }\end{array}$ & $\sigma$ & $\begin{array}{l}\text { N. Tunisia } \\
\text { TL }\end{array}$ & $\sigma$ & $\begin{array}{c}\text { Student } \\
\mathrm{t}\end{array}$ & $\begin{array}{c}\text { Egypt } \\
\text { TL }\end{array}$ & $\begin{array}{c}\text { S. Tunisia } \\
\text { TL }\end{array}$ & $\begin{array}{c}\text { E. Algeria } \\
\text { TL }\end{array}$ \\
\hline 1 & 16.52 & 3.14 & 15.46 & 1.42 & ns & 17.06 & 11.79 & 19.74 \\
\hline 2 & 27.92 & 5.32 & 24.83 & 2.75 & $*$ & 23.59 & 16.38 & 28.52 \\
\hline 3 & 36.74 & 6.77 & 34.33 & 2.86 & ns & 28.35 & 20.86 & 36.47 \\
\hline 4 & 43.50 & 7.82 & 42.38 & 3.44 & ns & 34.80 & 25.23 & 39.97 \\
\hline 5 & 49.88 & 8.14 & 46.91 & 4.53 & ns & 39.97 & 29.49 & 46.22 \\
\hline 6 & 55.93 & 8.21 & 54.09 & 4.12 & ns & 43.96 & 33.65 & 53.05 \\
\hline 7 & 62.55 & 8.50 & 60.06 & 4.91 & $\mathrm{~ns}$ & 47.54 & 37.70 & 56.76 \\
\hline 8 & 67.95 & 9.07 & 64.27 & 5.18 & ns & - & 41.65 & - \\
\hline 9 & 73.20 & 8.88 & 68.66 & 5.00 & ns & - & 45.51 & - \\
\hline 10 & 77.65 & 9.32 & 72.92 & 5.70 & ns & - & 49.27 & - \\
\hline 11 & 82.77 & 11.16 & 76.83 & 6.32 & ns & - & 52.94 & - \\
\hline 12 & 85.77 & 11.92 & 79.62 & 6.64 & ns & - & 56.51 & - \\
\hline 13 & 90.29 & 13.64 & 82.47 & 7.42 & $\mathrm{~ns}$ & - & 60.00 & - \\
\hline 14 & 94.73 & 15.54 & 85.29 & 7.51 & ns & - & 63.40 & - \\
\hline $\mathrm{L}_{\infty}$ & 135.91 & & 114.49 & & & 80.00 & 197.79 & 78.53 \\
\hline$K^{\infty}$ & 0.0791 & & 0.0928 & & & 0.112 & 0.025 & 0.16 \\
\hline $\mathrm{t}_{0}$ & -0.803 & & -0.751 & & & -1.086 & -1.459 & 0.73 \\
\hline
\end{tabular}




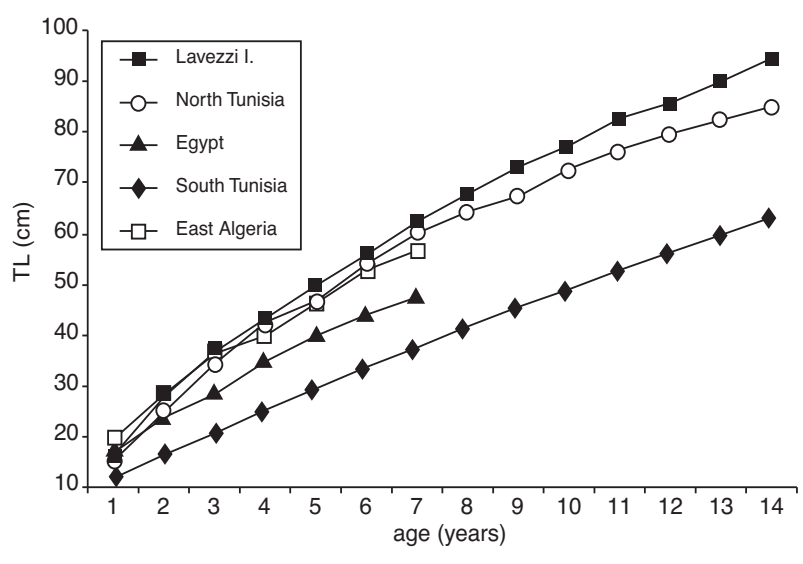

FIG. 3. - Linear growth comparison of E. marginatus; Egypt: Rafail et al. (1969); South Tunisia: Bouain (1984); North Tunisia: Chauvet (1988); East Algeria: Kara and Derbal (1995); Lavezzi Islands: present work.

\section{Length - weight relationship}

$\mathrm{W}$ : weight $(\mathrm{g})$ and TL: length $(\mathrm{cm})$

Relationship $\quad \mathrm{W}=0.125 \mathrm{TL}^{2.60}$

Linearised expression $\quad \mathrm{Ln} \mathrm{W}=2.598 \mathrm{Ln} \mathrm{TL}^{-2,079}$

where: variance of $\mathrm{Ln} \mathrm{W}=0.9592$; variance of $\mathrm{Ln}$ $\mathrm{TL}=0.1319$; covariance $=0.3375$; correlation coefficient: $r=0.9487$.

\section{DISCUSSION}

In the case of the growth equation obtained for 26 age classes, standard deviations of parameters $\mathrm{L}_{\infty}$ and $\mathrm{K}$ of the von Bertalanffy equation are artificially diminished by the utilization of the regression, thus allowing the determination of the size of older fishes using relative linear increases. Hence, only data obtained for fishes up to 14 years are used for the discussion.

\section{Linear growth}

The growth of Epinephelus marginatus was similar at the Lavezzi Islands and in North Tunisia, whereas the value of the annual growth rate $\mathrm{K}$ found was lower. According to Laurec and Le Guen (1981), it is necessary to remember that growth parameters are just simple mathematical supports and have no value as biological characters a priori since they are sensitive to age classes that make up the sample and to the mathematical procedures used to obtain them. This last point most likely explains the difference of $\mathrm{L}_{\infty}$ value as Chauvet's sampling (1988) included a larger number of small individuals.
The comparison of growth can be made with a test of comparison of means for size of each age class (Chauvet, 1988). This method has been used to compare results from Lavezzi to results from Tunisia (Table 4). The two series of mean lengths were not significantly different $\left(t>t_{0.05}\right)$, except for at the age of two years. This difference could be due to the low number of individuals studied in Lavezzi. It could also be explained by a difference in the intensity of intra juvenile competition in the two sectors; the density of groupers in Tunisia being more important than in the Lavezzi Islands. However, if this were the case, a difference should also be observed for age class 1. Similarly, standard deviations per age class were about two times greater in our study as compared to that of Chauvet (1988), but show the same trends.

The mean water temperature difference between the regions could also explain the differences in size between the fish at each site. The Lavezzi Islands have a status of natural marine reserve. They comprise an ecosystem possessing a great species richness and an increasing fish density (Bouchereau et al., 1989, 1992a, 1992b, 1997) as in the National Marine Park of Port-Cros (Francour and Harmelin, 1988). Marine bottoms around the Lavezzi Islands have an important trophic potential since they are covered by Posidonia. However, these seagrass beds offer few habitats to large fishes, as pointed out also by Derbal and Kara (1995) in the region of Annaba (Algeria). The groupers of this reserve are therefore over dispersed in rocky areas (Chauvet et al. 1991) without experiencing strong intra specific trophic competition. This would explain the good growth of $E$. marginatus in the Lavezzi Islands despite lower water temperatures $\left(12^{\circ} \mathrm{C}\right.$ to $25^{\circ} \mathrm{C}$; Culioli, 1994) than in Tunisia $\left(13^{\circ} \mathrm{C}\right.$ to $27^{\circ} \mathrm{C}$; Lemoalle et al., 1984).

Chauvet (1988) used growth parameter for comparison of the Pauly's index (1979):

$$
\mathrm{P}=\log \left(\mathrm{W}_{\infty} \mathrm{x}\right),
$$

with $\mathrm{W}_{\infty}$ in $\mathrm{g}$ and $\mathrm{K}$ in year ${ }^{-1}$.

This author found $\mathrm{P}=3.39$ from his data, $\mathrm{P}=$ 3.50 from Bouain's data (1984) and $\mathrm{P}=3.02$ from the data of Rafail et al. (1969). Pauly's index of the groupers from the Lavezzi Islands $\mathrm{P}=3.54$, agrees therefore with the index of the groupers from Tunisian coasts, which also differ from the index of Egyptian groupers. 


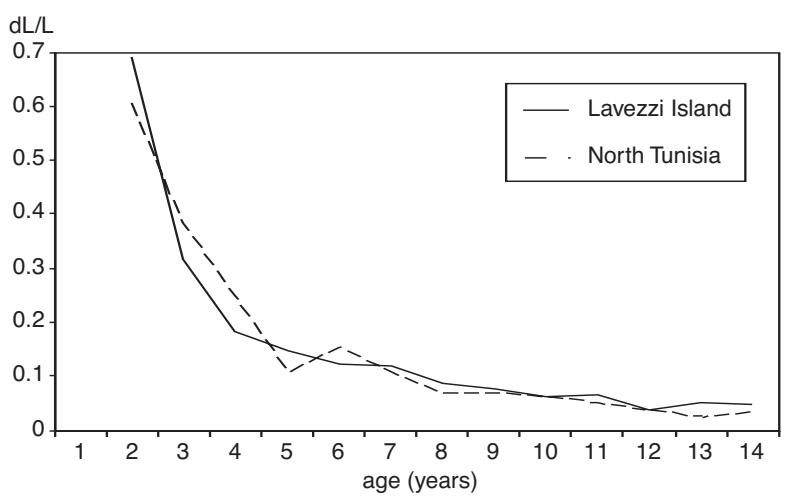

FIG. 4. - Annual evolution of the relative increase of the growth of E. marginatus from Tunisia (Chauvet, 1988) and the Lavezzi Islands (present work).

The homogeneity of growth of E. marginatus between Northern Tunisia and the Lavezzi Islands could reinforce the idea that these fishes are part of a single stock, as suggested by the study of the Grouper Study Group (G.E.M.: Groupe d'Etudes du Mérou; Anonymous, 1986 to 1994). The colonization of the northern parts of the Western Mediterranean basin should take place by the "process of advancement» from the South of the basin, especially the North African coasts (Chauvet et al., 1991; Chauvet and Francour, 1990).

The curve of relative increases calculated from North Tunisian fishes (Chauvet, 1988) shows a significant decline when fish are five years old (Fig. 4) which is explained by a diversion of energy at first sexual maturity, to the profit of ovogenesis. The curve of relative increases for the grouper from the Lavezzi Islands shows a more regular shape. The abundance of trophic resources in the marine reserve might be the cause. Nevertheless, this point can also enhance the idea suggested by observations of the GEM (Anonymous 1986 to 1994) that spawnings take place exceptionnaly north of latitude $41^{\circ} \mathrm{N}$. Over 20 years of observations (1974-1994) spawnings would not have taken place to the north of this latitude except in 1987, 1988 and 1989; observations reinforced by those of Camus et al. (1988), Bouchereau et al. (1989, 1992a, 1992b) and Tomasini et al. (1991). These last spawning events would explain the recent presence of small individuals (TL $<50 \mathrm{~cm}$ ) in captures by fishermen in this sector (Tomasini et al. (1991).

The dusky grouper has significant longevity (Chauvet, 1988), and although the oldest fish present in our sample was only 19 years old $(\mathrm{TL}=100$ $\mathrm{cm}$ ), older individuals have been found: 23 years for
Ancona (1937) and Bruslé and Prunus (1980), 24 years for Percier (1962), 36 years for Chauvet (1988), and Miraglia (1935) reported the death of a grouper in the aquarium of Napoli after 50 years in captivity.

\section{Length - weight relationship}

The exponent "b" of the relation $\mathrm{W}=\mathrm{aTL}$ is here $=2.598$ while the three other authors find a value significantly close to 3 . This weak value is compensated in the adjustment by a coefficient "a" 10 times higher than those found by the other authors and underlines simply the small size of the sample.

\section{Summary}

Despite the small number of specimens of $E$. marginatus for this study (22 individuals), results are largely agree with those found by Chauvet (1988) based on 270 individuals from North Tunisia. The relative abundance of trophic resources in the Lavezzi Islands, due to the reserve status of the zone, emphasized by a low density of grouper population, would play a role in the growth by compensating the opposite effects, of the water temperature. However, the most plausible explanation to account for the convergence of results between these two studies would be that these populations belong to a same metapopulation.

A suitable genetic study on the populations as well as a study on classic ecobiological parameters would allow to better account for the population dynamics of the dusky grouper in the Western Mediterranean basin.

\section{AKNOWLEDGEMENTS}

We thank Mr. J.-M. Culioli, Guard at the Natural Marine Reserve of Cerbicales and Lavezzi Islands, for collecting scales and taking size and weigth measurements of groupers landed by artisanal fishermen operating in the reserve. We also thank Dr. André Vaquer, UMR-CNRS 5556, for placing his image analyser at our disposal.

\section{REFERENCES}

Anonymous.- Rapports d'activités du Groupe d'Etude du Mérou. Rapports annuels du GEM. - 1986, 3: 1-30. - 1987, 4: 1-30. 1988, 5: 1-30. - 1989, 6: 1-30. - 1990, 7: 1-30. - 1991, 8: 1-30. 
- 1992, 9: 1-30. - 1993, 10: 1-30. - 1994, 11: 1-30.

Ancona, U. (D'). - 1937. La croissance chez les animaux méditerranéens. Rapp. PV Réun. CIESM, 10: 163-224.

Atz J.W. - 1964. Intersexuality in fishes. In: C. N. Amstrong and A. J. Marshall (ed.), Intersexuality in vertebrates including Man, pp. 145-232. Academic Press. New York.

Bertalanffy, L. (von). - 1934. Untersuchugen über die Gesetzlichkeit des Wachstums. Roux' Archiv für Entwicklungsmechanik, 131: 613-652 (Repris en français, In: Théorie générale des systèmes, Dunod, Paris, 176-190, (1968).

Bouain, A. - 1984. Contribution à l'étude des Serranidés des côtes tunisiennes. Thèse dr. Etat, Univ. Tunis: 393 p.

Bouchereau, J.-L. and T. Lam Hoai. - 1997. The ichthyofauna of the Lavezzi Islands (Corsica, France) at depths between 0 and $1 \mathrm{~m}$ : inventory, quantitative evaluation and recolonisation after experimantal destruction; Oceanological Studies, 27 (2-3): 191-207.

Bouchereau, J.-L., J.-A. Tomasini, J.-L. Fernez and R. Miniconi. 1989. Inventaire ichtyologique et évaluation quantitative de quelques espèces de Labridés, Serranidés et Sparidés des Iles Lavezzi. Trav. sci. Parc nat. rég. Rés. nat. Corse, Fr., 24: 1-34

Bouchereau J.-L., J.-A. Tomasini, C. Russ and J.-Y. Jouvenel. 1992a. Inventaire des poissons peuplant la Réserve Naturelle des iles Lavezzi. Trav. sci. Parc nat. rég. Rés. nat. Corse, Fr.: 39:1-11.

Bouchereau, J.-L., J.-A. Tomasini, C. Russ and J.-Y. Jouvenel. 1992b. Etude qualitative et quantitative de l'ichtyofaune de l'infralittoral des îles Lavezzi entre zéro et un mètre (Octobre 1990 et Mai 1991) Trav. sci. Parc nat. rég. Rés. nat. Corse, Fr. 39: $13-28$

Boudouresque, C.-F., M. Avon and V. Gravez. - 1991. Les espèces marines à protéger en Méditerranée. Colloque international des deuxièmes rencontres scientifiques de la Côte-Bleue, Carry-LeRouet, 18-19 novembre 1989, éd. GIS Posidonie, Marseille, France: $449 \mathrm{p}$.

Bruslé, J. - 1985. Exposé synoptique des données biologiques sur les mérous, Epinephelus aeneus (G. St-Hilaire, 1809) et $\mathrm{E}$ guaza (Linné, 1758) de l'Océan Atlantique et de la Méditerranée. FAO, Synopsis sur les pêches: 129: 1-64.

Bruslé, S. and J. Bruslé. - 1975. Ovarian and testicular intersexuality in two protogynous mediterranean groupers, Epinephelus aeneus and E. guaza, In: R. Reinboth (ed.), Intersexuality in the animal kingdom, pp. 222-227. Springer-Verlag, Berlin.

Bruslé, J. and G. Prunus. - 1980. Relations taille-poids chez les mérous méditerranéens, Epinephelus aeneus (G. St-Hilaire, 1809) et E. guaza (Linné, 1758). Cybium, (3ème sér.), 11: 1521

Camus P., J.-C. Joyeux and J.-L. Bouchereau. - 1988. Evaluation du peuplement ichtyique des Lavezzi. Trav. sci. Parc nat. rég. Rés. nat. Corse, Fr.: 17: 1-45.

Chauvet, C. -1981 . Calcul par otolithométrie de la relation log.-Td'Epinephelus guaza (Linné, 1758 ) de la côte nord de la Tunisie. Rapp. P.V. Commiss. Internation. Explor. Sci. Mer Médit.,.27(5): 103-106.

Chauvet, C. - 1988. Etude de la croissance du mérou Epinephelus guaza (Linné, 1758) des côtes tunisiennes. Aquat. Living Resour., 1: 277-288.

Chauvet, C. - 1991. Statut d'Epinephelus guaza (Linné, 1758) et éléments de dynamique des populations méditerranéenne et atlantique. In: Boudouresque C.F., M. Avon and V. Gravez, (edit.), Les Espèces Marines à Protéger en Méditerranée, pp. 255-275. GIS Posidonie publ., France.

Chauvet, C., G. Barnabé, J. Bayle Sempere, C.H. Bianconi, J.-L. Binche, P. Francour, A. Garcia-Rubies, J.-G. Harmelin, R. Miniconi, A. Pais and P. Robert. - 1991. Recensement du mérou Epinephelus guaza (Linné, 1758) dans les réserves et parcs marins des côtes méditerranéennes françaises. In: Boudouresque C.F., M. Avon and V. Gravez, (edit.), Les Espèces Marines à Protéger en Méditerranée, pp. 277-290. GIS Posidonie publ., France.

Chauvet, C and P. Francour. - 1990. Les mérous Epinephelus guaza (Linné, 1758) du parc National de Port-Cros (France), Bull.
Soc. Zool. France, 114 (4): 5-13.

Culioli, J.M. - 1994. La pêche professionnelle dans la réserve Naturelle des Iles Lavezzi (Corse). Effort et Productions, DES de l'Université Montpellier II, 183 p.

Derbal, F. and M. H. Kara. - 1995. Habitat et comportement du mérou Epinephelus marginatus dans la région d'Annaba (Algérie), Cah. Biol. Mar., 36: 29-32.

Francour, P. and J.-G. Harmelin. - 1988.- Inventaire ichtyologique marine de Port-Cros (Méditerranée occidentale). Trav. Sci. Parc Natl Port-Cros, 14: 65-79.

Franqueville, C. and P. Fréon. - 1976. Relations poids-longueurs des principales espèces de poissons marins du Sénégal. Doc. Sc. Centre de Recherche Océanographique de Dakar, 60: 1-37.

Grill, C. - 1989. Application de la morphométrie mathématique en analyse d'image. Programmes pour micro-ordinateurs PC-AT ou compatibles. Lab. microscopie électronique, Univ. Montpellier II.

Lemoalle, J., Vidy G., Franc J. - 1984. Rapport d'étude sur la lagune El Bibane. Commissariat général de la pêche, Ministère de l'agriculture de la République tunisienne-ORSTOM, 268p.

Kara, M. H. and F. Derbal. - 1995. Morphométrie, croissance et mortalité du Mérou Epinephelus marginatus (Serranidae) des côtes de l'est algérien, Cah. Biol. Mar., 36: 229-237.

Lam Hoai, T. - 1989. Programme BASIC pour l'étude des populations et des écosystèmes. Rapport technique (diffusion restreinte), Lab. hydrobiol., Univ. Montpellier II, 10 p.

Lam Hoai, T. - 1992. Système d'analyse d'image en biologie des organismes et des populations. Rapport technique (diffusion restreinte), Lab. hydrobiol., Univ. Montpellier II, 7 p.

Laurec, A. and J.-C. Le Guen. - 1981. Dynamique des populations marines exploitées. Rapports Scientifiques et Techniques, 45. Centre National pour l'exploitation des Océans.

Lee, R. M. - 1920. A review of the methods of age and growth determination in fishes by mean scale. Fish. Invest. London, 2, $32 \mathrm{p}$.

Miraglia, L. - 1935. Nuevo sistema di osservazione di caccia subacquea. Boll. Pesca Piscicol. Idrobiol., 11 p.

MNHN. - 1987. Livre rouge des espèces menacées en France; Tome 2: espèces marines et littorales menacées. Museum National d'Histoire Naturelle, Paris, France, Sec. Faune et Flore, 357pp

Pauly, D. - 1979. Gill size and temperature as governing factors in fish growth: a generalization of von Bertalanffy's Growth Formula. Ber. Inst. Meeresk., 63, 156p.

Percier, A. - 1962. Espèces marines recommandables en raison de leur résistance. Ann. Inst. océanogr. Monaco, 1A: 1-6.

Rafail, S.Z., W.L. Daoud and M.M. Hilal. - 1969. Longline Mediterrannean fisheries studies west of Alexandria. CGPM Etud. Rev./GF CM Stud. Rev. 42: 3-16.

Smith, C. L. - 1959. Hermaphrodism in some Serranid fishes from Bermuda. Pap. Mich. Acad. Sci. Arts Lett., 44: 111-190.

Smith, C. L. - 1971. A revision of the american groupers: Epinephelus and allied genera. Bull. Am. Mus. nat. Hist., 146: 67-242.

Tomasini, J.-A., J.-L. Bouchereau and C. Russ. - 1991. Etude qualitative et quantitative et variations saisonnières (Juillet 1987 et 1988-Octobre 1989) de l'ichtyofaune des îles Lavezzi. Trav. sci. Parc nat. rég. Rés. nat. Corse, Fr., 32: 1-37.

Tomlinson, P. K.and N.J. Abramson. - 1961. Fitting a von Bertalanffy growth curve by the least squares. Calif. Fish. Game Fish. Bull., 116: 1-69.

Tortonese, E. - 1954. Zoogeography of the Mediterranean sea perchs (Pisces Serranidae). Rapp. PV. Réun. CIESM, 12: 93103.

Tortonese, E. - 1967. Citeva note comparative prinive pestii diu Mediterranea si diu Marea Neagra. Bull Inst. Cerc. Piscic., 26: $37-54$.

Wheeler, A., R.W. Blacker and S.F. Pirie. - 1975. Rare and little known fish in British seas in 1970 and 1971. J. Fish. Biol., 7: 183-201.

Scient. ed.: H. Ferrugio 